Surkhet

\title{
Critical Incidents for Teachers' Professional Development
}

\author{
- Khem Raj Joshi
}

\begin{abstract}
Analysis of critical incidents is one of the approaches of teacher professional development. A critical incident is any unplanned event which takes place during the class. It is something we interpret as a problem or challenge in a particular context, rather than a routine occurrence. The incident is said to be critical because it is valuable and has some meaning. In other words, incidents happen but critical incidents are created because of their importance. Teachers can critically analyze any of their lessons and can make a particular event critical by reflecting on it. The teachers ask not only what happened but also why it happened. They then use the incidents for future reference. This article deals with the benefits of critical incidents and the ways to analyze them, which lead to successful teacher professional development.
\end{abstract}

Key words: Critical incident, Professional development, and CIQ (Critical incident questionnaire)

\section{What are Critical Incidents?}

A critical incident is something which we interpret as a problem or a challenge in a certain context. It is not a routine occurrence, for example, when a student constantly arrives late in the class, when some students make noise while teachers are teaching, etc. A critical incident is often personal to an individual teacher. A critical incident is defined by different scholars in different ways. Some of them are presented here.

A critical incident is any unplanned and unanticipated event that occurs during class, outside class or during a teacher's career but is "vividly remembered" (Brookfield, 1990, p. 84). Likewise, Tripp (1993) stated that "... a critical incident is an interpretation of the significance of an event. To take something as a critical incident is a value judgment we make, and the basis of that judgment is a significance we attach to the meaning of the incident" (p. 8). He further says: 
The term 'critical incident' comes from history where it refers to some event or situation which is marked a significant turning-point or change in the life of a person or an institution... The vast majority of critical incidents, however, are not at all dramatic or obvious: they are mostly straight forward accounts of very common place events that occur in professional practice which are critical in the rather different sense that they are indicative of underlying trends, motives and structures. These incidents appear to be 'typical' rather that 'critical' at first sight, but are rendered critical through analysis (pp. 24-25).

Similarly, Richards and Farrell (2010) mention that "a critical incident is an unplanned and unanticipated event that occurs during a lesson and that serves to trigger insights about some aspect of teaching and learning" (p. 13). They say that critical incident analysis refers to the documentation and analysis of teaching incidents in order to learn from them and improve practice. Such incidents compel teachers to ruminate the long-term implications they may have. This process of documentation and reflection provides opportunity for teachers "to learn more about their teaching, their learners and themselves" (ibid, p. 114). These above mentioned definitions and ideas about critical incidents exhibit that a critical incident in teaching refers to a particular occurrence that has taken place during a lesson. Teachers make it critical because they think it important and want to utilize it for future reference. In other words, teachers sometimes face some unexpected situations which make them surprised. They take such situations to be critical because they learn something from them.

When something goes wrong in the classroom or outside classroom, teachers need to ask what happened and what caused it to happen. Researchers say that the incidents can be framed as questions. For example, if students come late to the class, the teachers can begin with the question 'Why do they come late?' If incidents are analyzed in this way, they can become the turning points in the teachers' career and can lead to changes. Critical incidents can be both positive and negative classroom events. For example;

- Sometimes teachers plan to engage their learners in communicative activities to promote their speaking ability. But in the classroom, they may find their students' participation more than they had expected and the better speaking practices and outcomes. Though it is a commonplace event, a teacher can take it as a critical incident because s/he may interpret it to be significant for future reference.

- Sometimes teachers plan to conduct group work activities. They tell their students what they are going to do; divide them into groups; assign tasks, etc. and the students start performing them. The teacher thinks that his students are on the right track. But one of the students may ask "What are we supposed to do?"

- A teacher may check the written responses of his students. S/he only marks "excellent", "well done", "keep it up" etc. regularly on a brilliant student's notebook. S/he thinks that 


\section{Critical Incidents for Teachers'Professional Development}

the student has achieved what is expected from his level. But at the end of the session, that student may say "If you had sometimes asked me to work harder, I would have done better."

- A teacher prepares and presents different models of lesson plans to teach different aspects (e.g. grammar, vocabulary) and skills (listening, speaking, reading, writing) and also spends a couple of weeks engaging students in practising how to prepare lesson plans for teaching different aspects and skills. They prepare the plans and teach model lessons also. But one of the students may ask "What actually is the format for preparing a lesson plan?"

The above examples are the incidents that happen in classroom as commonplace events. But they are critical incidents in the sense that they reveal underlying beliefs and motives within the classroom. At the first appearance, these incidents seem to be insignificant but soon they become critical when they are subject to review and analysis since they trigger a sense of weird occurrence in the particular situation. These types of incidents can be called critical incidents because they are unexpected and they prompt the teachers to stop and think about the meaning of such events so that they improve (if negative incident) their teaching in future. All incidents that take place in the classroom may not be critical. A particular event becomes critical incident depending on how it is interpreted. Sometimes teachers themselves come to interpret an incident to be critical. Sometimes they take help of their students.

\section{Why Analyze Critical Incidents?}

Analysis of critical incidents helps teachers know more about how they teach. It also helps them to question their own teaching practice which enables them to develop professionally. The main purpose of analyzing a critical incident is to identify good practices of teaching a teacher is adopting. It also aims to identify those practices which are not working well. It serves as a form of reflective inquiry and a sense of professional awareness. Analyzing critical incidents has a number of benefits. It helps the teachers identify and solve problems. According to Richards and Farrell (2010), analyzing critical incidents facilitates teacher professional development in the following ways:

- It can create a greater level of self-awareness: When teachers analyze critical incidents they encounter in their classes, they become more aware of what they are doing. As a result, they can notice a gap between what they are doing and what they are supposed to do.

- It can prompt an evaluation of established routines and procedures: There may be some techniques or strategies of teaching preferred by a teacher or in an institution which have become the established routines. It means they are the procedures taken for granted. But when a teacher analyzes critical incidents, s/he can evaluate such routinized techniques on the basis of how his/her students are responding to those techniques. 
- It can encourage teachers to pose critical questions about teaching: Once teachers start analyzing critical incidents occurring in their classes, they develop the habit of looking at everything critically. They become careful about whether something they are going to adopt will really work or not. In other words, they ask themselves questions from each and every aspect.

- It can help bring beliefs to the level of awareness: Teachers hold several different types of beliefs about different dimensions of teaching. And the beliefs they hold about learners, learning, teaching, etc. have an influence on the way they teach. When teachers analyze critical incidents, they become aware of their beliefs and can also change them, if necessary.

- It can create opportunities for action research: An action research is a classroom research that a teacher conducts to solve some practical and real problems in his/her classes. After analyzing the critical incidents, teachers can focus their attention on some particular problems and can carry out action research to solve those problems.

- It can help build a community of critical practitioners: Teachers can share the critical incidents they encounter with their colleagues. As a result, they develop the sense of collegiality. And other teachers who analyze the incidents also begin to see teaching in a critical way.

- It can provide a resource for teachers: When teachers keep a record of critical incidents of their classes, this compilation can be used as a resource by both new teachers and experienced teachers and this compilation can be used as a reference for future professional development.

\section{How to Analyze Critical Incidents?}

Scholars have given different frameworks to analyze critical incidents. One of the procedures to analyze critical incidents is to examine and understand the critical incident itself. Tripp (1993) has suggested that there are two stages to understanding a critical incident:

- Stage 1: to describe the incident (i.e. the "what" aspect): This is the description phase. In this phase, a specific phenomenon or an issue is observed and documented.

- Stage 2: to explain its meaning (i.e. the "why" aspect): In this phase, the issue is explained by the teacher in terms of its meaning or value. It is also interpreted in terms of the role it plays.

It shows that at first, an incident is described and then, it is decided why it is interpreted as a critical incident. Only those incidents which have significance in a wider context are viewed to be the critical incidents. When teachers report the critical incidents, they should follow certain steps: self-observation, describing what happened, self-awareness, and self-evaluation (Thiel, 1999): 


\section{Critical Incidents for Teachers'Professional Development}

- Self-observation: Teachers adopt different ways to observe and record their own teaching such as written narrative, audio videotaping, keeping a teaching journal, etc. The first step in analyzing critical incident is to identify all the significant and relevant events that occur in the classroom through any of the above ways and write them in the note form.

- Describing what happened: This is the second step in preparing critical incident report where teachers write a detailed description of what actually happened in their classes. This detailed description should be related to the incident which is interpreted to be critical or significant.

- Self-awareness: In this step, the teacher explains the way particular incident occurred. The teacher tries to look at the incident from every possible angle to explain why it happened.

- Self-evaluation: This step is said to be the most difficult of all. In this final step, the teacher evaluates what changes were caused due to the incident in his/her practices in teaching.

In the similar way, McCabe (2002) presents the following framework for analyzing the critical incident from the narrative perspective:

- Orientation: This part answers the questions like: Who? When? What? and Where?

- Complication: This part outlines what happened and the problem that occurred along with any turning point in the story.

- Evaluation: This part answers the question: So what?

- Result: This part outlines and explains the resolutions to the problem.

In the process of analyzing and preparing a report of critical incidents, teachers often need to reflect on the critical incidents. The following questions can help the teachers reflect on a critical incident: Why was this incident significant to you?; What happened directly before the event?; What happened directly after the event?; How did you react at the time of the event?; What is your interpretation of this event?; What underlying assumptions about your teaching does this critical incident raise for you?; Now that you have reflected on this critical incident, would you react any differently if it happened again? Why or why not? (Richards and Farrell, 2010, p. 120).

\section{How to Identify Critical Incidents?}

Most of the critical incidents occur in the classrooms but some critical events influence the teachers' personal and professional life. For example, a teacher may attend a workshop or a conference where $\mathrm{s} / \mathrm{he}$ is exposed to several different new practices. S/he may interpret any of them as a valuable, critical incident which influences his/her attitude towards the existing practices. Then, s/he may decide to adopt this new practice in his/her classes. It is said that teachers need to develop their understanding of teaching and of themselves. According to 
Freeman (1996), it is necessary for teachers to put themselves at the center of telling their life stories. He says that it follows a jazz maxim: "you have to know the story in order to tell the story" (p. 89). Bartlett (1990) presents some questions to be addressed while reflecting on personal critical incidents in teaching career: Why did I become a language teacher?; Do these reasons still exist for me now?; How has my background shaped the way I teach?; What does it mean to be a language teacher?; Is the teacher I am the person I am?; What is my philosophy of language teaching?; Where did this philosophy come from?; How was this philosophy shaped?; What are my beliefs about language learning?; What critical incidents in my training to be teacher shaped me as a teacher?; Do I teach in reaction to these?; What critical incidents in my career shaped me as a teacher?; Do I teach in reaction to these critical incidents?

Brookfield (1990) emphasizes the use of critical incident questionnaire (CIQ) in order to identify the feelings of the students regarding teaching out of which teachers can identity which incident is critical and which is not from the words of students. This sort of activity can help teachers deal with similar incidents in the future. Brookfield (ibid) stated that CIQ is a quick and revealing way to discover the effects your actions are having on students and to find out the emotional highs and lows of their learning. Administering CIQ, according to him, just takes a short time. The students are asked to write answers to a few questions without putting their name on the form. This is done on a weekly basis. Some examples of the questions used in the CIQ are as follows:

- At what moment in class this weekend did you feel most engaged with what was happening?

- At what moment in class this weekend were you most distanced from what was happening?

- What action that anyone (teacher or student) took this weekend did you find most affirming or helpful?

- What action that anyone took this weekend did you find most puzzling or confusing?

- What about the class this weekend surprised you the most?

\section{Conclusion}

For the successful implementation of a critical incident analysis, different aspects should be considered, for example, who the audience for the analysis is, whether we need to write about all the incidents, etc. All incidents are not critical. We interpret a certain incident to be critical depending on the situation and purpose. Another equally important thing to be considered is whether teachers decide any incident to be critical for analyzing it or they collect their students' relevant feeling to choose from and so on. Thus, a critical incident is an unplanned and an unexpected event that occurs during the lesson. The report of a critical incident can be added in a teacher's portfolio to show the evidence of how s/he changes some practices of teaching being used. Teachers learn from their analysis of critical incidents and improve their ways of teaching. 


\section{References}

Bartlett, L. (1990). Teacher development through reflective teaching. In J.C. Richards and D. Nunan. (eds). Second language teacher education. New York: CUP.

Brookfield, S. D. (1990). The skillful teacher. San Francisco: Jossey Bass.

Freeman, D. (1996). Redefining research and what teachers know. In K. Bailey and D. Nunan. (eds). Voices from the language classroom. New York: CUP.

McCabe, A. (2002). A wellspring for development. In J. Edge. (eds). Continuing professional development. UK: IATEFL Publications.

Merriam, S. B., \& Caffarella, R. S. (1999). Learning in adulthood: A comprehensive guide. San Francisco: Jossey Bass.

Richards, J. C., \& Farrell, T. S. C. (2010). Professional development for language teachers. Cambridge: CUP.

Stronge, J. (1997). Evaluating teaching: A guide to current thinking and best practice. California: Corwin Press.

Thiel, T. (1999). Reflections on critical incidents. Prospect, Vol. 14 (1), pp.44-52.

Tripp, D. (1993). Critical incidents in teaching. London: Routledge. 